\title{
Growth performance, feeding behavior, health status, and blood metabolites of environmentally heat-loaded Holstein dairy calves fed diets supplemented with chromium
}

\author{
S. Kargar, ${ }^{* 1}$ F. Mousavi, $†$ S. Karimi-Dehkordi, $†$ and M. H. Ghaffari $\ddagger^{2}$ \\ *Department of Animal Science, School of Agriculture, Shiraz University, Shiraz 71441-65186, Iran \\ †Department of Animal Science, College of Agriculture, Shahrekord University, Shahrekord 34141-88186, Iran \\ fDepartment of Agricultural, Food, and Nutritional Science, University of Alberta, Edmonton T6G 2P5, Canada
}

\begin{abstract}
We investigated the effect of Cr supplementation on growth performance, feeding behavior, health status, and blood metabolites of summer-exposed dairy calves during the pre- and postweaning periods. A total of 24 newborn Holstein female calves (1 d of age; $42.1 \pm$ $0.89 \mathrm{~kg}$ of body weight) were assigned randomly to a control group (no $\mathrm{Cr}$ supplement; $\mathrm{Cr}-$ ) or a $\mathrm{Cr}$ group $(\mathrm{Cr}+)$ receiving $0.05 \mathrm{mg}$ of $\mathrm{Cr} / \mathrm{kg}$ of body weight ${ }^{0.75}$. During the study period, the average maximum temperature-humidity index was 81.3 units, indicating a high environmental heat load. Chromium was provided in colostrum and milk during the preweaning period, and in the starter feed during the postweaning period. Calves had free access to fresh water and starter feed throughout the experiment and were weaned on $\mathrm{d} 63$. Starter feed intake and total dry matter intake were greater in $\mathrm{Cr}+$ calves. Despite decreased meal frequency in $\mathrm{Cr}+$ calves, during the preweaning period the starter feed intake increased due to increases in meal duration and meal size and a tendency for greater meal interval. Increased postweaning starter intake in $\mathrm{Cr}+$ calves was attributed to a tendency for an increase in meal duration. Chromium-supplemented calves had greater overall weight gain, but their feed efficiency and rectal temperature were not affected by Cr treatment. Chromium supplementation tended to increase the heart girth during the preweaning and overall periods and increased the hip width during the postweaning and overall periods. Respiration rates were lower in $\mathrm{Cr}+$ calves than $\mathrm{Cr}-$ calves during the preweaning and overall periods. During the preweaning period, the time spent in eating and ruminating per 12 -h period was not affected by $\mathrm{Cr}$ treatment. During the postweaning
\end{abstract}

\footnotetext{
Received November 19, 2017.

Accepted June 27, 2018.

${ }^{1}$ Corresponding author: skargar@shirazu.ac.ir or skargar@wisc.edu

${ }^{2}$ Current address: Institute of Animal Science, Physiology \& Hygiene Unit, University of Bonn, 53115 Bonn, Germany.
}

period, the rumination time (min per 12 -h period) was unaffected but total eating time (min per 12 -h period) increased in $\mathrm{Cr}+$ calves. Times spent resting, drinking, standing, lying, and in nonnutritive oral behaviors were not affected by treatments during the pre- and postweaning periods. Chromium supplementation had no effects on serum concentrations of cortisol, triiodothyronine, and thyroxine measured at weaning or the end of the trial. The $\mathrm{Cr}+$ calves tended to have higher serum concentrations of glucose and a higher ratio of insulin to glucose measured at the end of the trial. In conclusion, Cr supplementation of both liquid and solid feeds improved growth performance in summer-exposed calves as a result of reduced respiration rate and increased feed intake; however, no beneficial effects were found on feed efficiency and insulin metabolism.

Key words: dairy calf, chromium, summer

\section{INTRODUCTION}

During summer months, calves exhibit poor growth performance (West, 2003), low immunity (Tao and Dahl, 2013), increased respiratory rate (Spain and Spiers, 1996), and greater susceptibility to diseases due to reduced feed intake (West, 2003). The consequences of thermal stress are costly due to economic losses associated with reduced weight gain, and increased mortality and morbidity (Roland et al., 2016). Chromium supplementation may be a viable approach to improve calf performance and welfare during summer as it may alleviate the negative effects of environmental stress (Pechova and Pavlata, 2007) and improve the physiological responses in dairy calves exposed to thermal stress (Yari et al., 2010). Chromium as a part of chromodulin (also called low-molecular-weight chromium-binding substance) plays an important role in the activation of insulin receptor and allows glucose to enter the cells by recruiting the GLUT 4 transporters from the interior of cells to the cell surface (Vincent, 2015). In buffalo calves, dietary Cr supplementation (0.5 to $1.5 \mathrm{mg} / \mathrm{kg}$ of $\mathrm{DM}$ ) during the summer months 
improved their heat tolerance and immune status, and the effectiveness of insulin with no effects on feed intake, growth performance, or triiodothyronine $\left(\mathbf{T}_{3}\right)$ and thyroxine $\left(\mathbf{T}_{4}\right)$ concentrations (Kumar et al., 2015).

Beneficial effects of $\mathrm{Cr}$ supplementation on production responses in dairy cows during normal (Sadri et al., 2009) and heat stress conditions (Soltan, 2010) were also reported. However, the data on the effect of $\mathrm{Cr}$ supplementation on intake and growth performance in calves are not consistent (Yari et al., 2010; Ghorbani et al., 2012; Kumar et al., 2015). Such inconsistencies may be explained by (1) the chemical form of $\mathrm{Cr}$ used [inorganic $\left(\mathrm{CrCl}_{3}\right)$ vs. organic (Cr-yeast or chelated-Cr; Kegley and Spears, 1995)], (2) environmental conditions (normal vs. heat stress condition), (3) method of offering $\mathrm{Cr}$ (in the starter or liquid feed), or (4) $\mathrm{Cr}$ dosage.

There is a paucity of data describing the effect of $\mathrm{Cr}$ supplementation on the starter feed intake, growth performance, feeding behavior, health status, and blood metabolites in dairy calves under summer conditions. Furthermore, the mechanism by which feed intake may be affected by $\mathrm{Cr}$ supplementation is not completely clear. Investigation of feeding behavior in Cr-supplemented calves is also required to clarify the mechanism through which $\mathrm{Cr}$ affects the feed intake. The objective of this study was to determine the effect of $\mathrm{Cr}$ supplementation on feed intake, meal pattern, health status, blood metabolite, and growth performance in environmentally heat-loaded newborn Holstein calves during the pre- and postweaning periods. It was hypothesized that supplemental $\mathrm{Cr}$ would enhance growth performance in dairy calves during summer, possibly through increased starter feed intake.

\section{MATERIALS AND METHODS}

This study was conducted from July 5 to October 12, 2015, at the FKA Agri-Animal Production Co., Isfahan, Iran. Animal experimentation followed the protocol \#19356 of the Iranian Council of Animal Care (1995). Air temperature and relative humidity $(\mathbf{R H})$ in the stall areas were recorded daily by Hobo Pro Series Temp probes (Onset Computer Corporation, Pocasset, MA). Temperature-humidity index (THI) was calculated using the equation: $\mathrm{THI}=0.8 \times$ maximum $\mathrm{T}+$ $($ minimum $\mathrm{RH} / 100) \times($ maximum $\mathrm{T}-14.4)+46.4$, in which $\mathrm{T}$ is the air temperature $\left({ }^{\circ} \mathrm{C}\right)$ and $\mathrm{RH}$ denotes the relative humidity (\%; NRC, 2001).

\section{Calves, Treatments, and Management}

Twenty-four newborn Holstein female calves (1 d old; $42.1 \pm 0.89 \mathrm{~kg}$ of $\mathrm{BW} \pm \mathrm{SE}$ ) were separated from their dams immediately after birth, weighed, and randomly transferred to individual pens $(2.9 \mathrm{~m} \times 1.1 \mathrm{~m} \times 1.8$ $\mathrm{m}$; length $\times$ width $\times$ height). Fresh sawdust bedding was added every $3 \mathrm{~d}$, but manure was removed daily as needed to keep the pens visibly clean and dry. Each calf was fed $6 \mathrm{~L}$ of colostrum over $2 \mathrm{~d}$ starting from 2 to $8 \mathrm{~h}$ after birth. From d 2 onward, the calves were individually fed pasteurized waste milk, containing 3.34 $\pm 0.12 \%$ fat, $2.86 \pm 0.09 \% \mathrm{CP}$, and $4.87 \pm 0.07 \%$ lactose, in steel buckets in 2 meals of equal volume (daily at 0800 and $1600 \mathrm{~h}$ ). Milk was pasteurized by heating for $30 \mathrm{~min}$ at $62.5^{\circ} \mathrm{C}$ (Pazoki et al., 2017). Representative samples of milk $(\mathrm{n}=36)$ were taken from both the morning and evening meals twice per week, preserved with potassium dichromate, stored at $4^{\circ} \mathrm{C}$, and then analyzed for concentrations of fat, protein, and lactose by MilkoScan (134 BN Foss Electric, Hillerød, Denmark; AOAC International, 1990). The calves were offered milk $3 \mathrm{~L} / \mathrm{d}$ from 3 to $15 \mathrm{~d}$ of age, $4 \mathrm{~L} / \mathrm{d}$ from 16 to $20 \mathrm{~d}$ of age, $5 \mathrm{~L} / \mathrm{d}$ from 21 to $25 \mathrm{~d}$ of age, $6 \mathrm{~L} / \mathrm{d}$ from 26 to $60 \mathrm{~d}$ of age, and $3 \mathrm{~L} / \mathrm{d}$ from 61 to $63 \mathrm{~d}$ of age. The calves were weaned on d 63 and the study was terminated on d 91. Calves were assigned randomly to 2 treatments $(\mathrm{n}=12)$ : a control group $(\mathbf{C r}-)$ and a group receiving supplemental $\mathrm{Cr}(\mathbf{C r}+)$. The rate of chromium supplementation was chosen according to Vincent (2014), who suggested doses between 0.08 to 1 $\mathrm{mg}$ of $\mathrm{Cr} / \mathrm{kg}$ of $\mathrm{BW}$ for a positive effects of $\mathrm{Cr}$ on metabolism. Chromium was added to the liquid feed (300 $\mathrm{mL}$ of colostrum or milk) and fed to calves in bottles up to wk 9 to supply $0.05 \mathrm{mg}$ of $\mathrm{Cr} / \mathrm{kg}$ of $\mathrm{BW}^{0.75}$; the calves received the remaining colostrum/milk according to the feeding schedule described above. The chromium supplement [MicroPlex 1000, supplied 1,000 mg of $\mathrm{Cr} /$ $\mathrm{kg}$ as Cr-Met (90\% Met and $10 \% \mathrm{Cr}$, wt/wt); Zinpro Animal Nutrition Inc., Eden Prairie, MN] was provided by Sana Dam Co. (Tehran, Iran). After weaning, the same dosage of $\mathrm{Cr}$ was added in the starter feed. To ensure that each calf consumed the calculated amount of $\mathrm{Cr}$, the Cr-Met was mixed with $50 \mathrm{~g}$ of daily starter feed allowance and top-dressed. Chromium supplementation was adjusted based on weekly BW throughout the entire experimental period (Yari et al., 2010; Ghorbani et al., 2012). Adjustment of the level of $\mathrm{Cr}$ fed each week is not how Cr would be expected to be supplemented in real world feeding situations; therefore, feeding rates of Cr supplements should be based on the manufacturer's recommendations.

Calves were provided ad libitum access to fresh water and starter feed (mashed form) formulated according to the Cornell Net Carbohydrate and Protein System, version 5.1 (CNCPS), allowing at least $10 \%$ refusals (i.e., the portion of the starter not consumed over a 24-h period). Grains (corn and barley), used in the 
starter feed, were ground using a hammer mill with a 2-mm screen size (model 5543 GEN, Isfahan Dasht, Isfahan, Iran). Second-cut alfalfa hay at $50 \%$ flowering was chopped (particle size distribution: $5.0 \pm 0.3 \%$ greater than $18 \mathrm{~mm}, 28.9 \pm 1.4 \%$ between 8 and 18 $\mathrm{mm}, 41.8 \pm 0.9 \%$ between 1.18 and $8 \mathrm{~mm}$, and $24.3 \pm$ $1.3 \%$ less than $1.18 \mathrm{~mm}$, and geometric mean particle $4.05 \pm 0.14 \mathrm{~mm}$ ) with a theoretical length of $30 \mathrm{~mm}$, using a harvesting machine with screen size regulator (Golchin Trasher Hay Co., Isfahan, Iran). Calves received a starter feed containing $8 \%$ alfalfa hay as TMR with concentrate throughout the study. The ingredients and nutrient composition of the basal diet are shown in Table 1. Starter feed refusal was removed at 0800 h. Feed or refusal were mixed thoroughly and ground to pass a 1-mm screen in a Wiley mill (Ogawa Seiki Co., Ltd., Tokyo, Japan) before samples were analyzed for DM (AOAC International, 1990; method 934.01) and CP (AOAC International, 1990; method 988.05) contents. Neutral detergent fiber was analyzed without

Table 1. Ingredients and chemical composition of the experimental starter diet on a DM basis

\begin{tabular}{lr}
\hline Item & Diet \\
\hline Ingredient composition, \% of DM & \\
Alfalfa hay & 8.0 \\
Corn grain, ground & 43.9 \\
Barley grain, ground & 9.2 \\
Soybean meal & 29.4 \\
Extruded soybean & 4.7 \\
Fat supplement ${ }^{1}$ & 0.5 \\
Calcium carbonate & 1.7 \\
Sodium bicarbonate & 1.1 \\
Monocalcium phosphate & 0.5 \\
Vitamin and mineral mixture ${ }^{2}$ & 0.5 \\
Salt & 0.5 \\
Chemical composition, \% of DM unless & \\
otherwise indicated & \\
DM, \% & 89.2 \\
CP & 21.6 \\
NFC & 53.1 \\
NDF & 14.7 \\
ADF & 6.3 \\
Ether extract (EE) & 4.3 \\
Ash & 4.3 \\
Calcium ${ }^{4}$ & 0.98 \\
Phosphorus ${ }^{4}$ & 0.52 \\
Chromium, mg/kg of DM & 0.95 \\
ME, ${ }^{4}$ Mcal/kg of DM & 3.10 \\
NE ${ }^{4}{ }^{M}$ Mcal/kg of DM & 2.32 \\
NE ${ }_{\mathrm{G}}{ }^{4}$ Mcal/kg of DM & 1.76 \\
\hline
\end{tabular}

${ }^{1}$ Palmac 80-16 (IOI Oleochemical Industries Sdn Bhd, Prai, Malaysia). Product contained 2\% C12:0, 5\% C14:0, 80\% C16:0, 2\% C18:0, 9\% $\mathrm{C} 18: 1$, and $3 \% \mathrm{C} 18: 2$.

${ }^{2}$ Contained per kilogram of supplement: 975,000 IU of vitamin A, $750,000 \mathrm{IU}$ of vitamin D, 1,800 IU of vitamin E, $143 \mathrm{~g}$ of $\mathrm{Zn}, 76 \mathrm{~g}$ of $\mathrm{Mn}, 48.6 \mathrm{~g}$ of $\mathrm{Cu}, 19.5 \mathrm{~g}$ of Se, $18.4 \mathrm{~g}$ of Fe, $8 \mathrm{~g}$ of Ca, and $1.3 \mathrm{~g}$ of Co. ${ }^{3} \mathrm{NFC}=100-(\mathrm{CP}+\mathrm{NDF}+\mathrm{EE}+\mathrm{ash})(\mathrm{NRC}, 2001)$.

${ }^{4}$ Calculated from NRC (2001). sodium sulfite but with $\alpha$-amylase included (Van Soest et al., 1991).

\section{Data Collection and Sampling}

Sub-samples of the starter feed $(\mathrm{n}=13$; one sample per week) were prepared (Nasrollahi et al., 2012) and analyzed for $\mathrm{Cr}$ contents (flame photometer; GBC Integra EXL ICP, Melbourne, Australia). Glassware were acid-washed to avoid sample contamination; a blank was run with the samples to test for possible contamination. The amount of starter feed intake was calculated based on the weight of feed offered and refusal collected daily. The calves were weighed at birth and once weekly thereafter using an electronic scale, which was calibrated by the manufacturer's agent before initiation of the study and every month thereafter. Average daily weight gain $(\mathrm{kg} / \mathrm{d})$ and gain-to-feed ratio $[\mathrm{kg}$ of $\mathrm{BW}$ gain $/$ total DMI $(\mathrm{DMI}=$ milk $\mathrm{DM}+$ starter feed DM)] were calculated. In addition, the barrel, heart girth, and hip width measurements were recorded weekly (Pazoki et al., 2017). Respiration rate (RR) was measured at $1400 \mathrm{~h}$ daily by visual observation at 3 separate minutes (Kargar et al., 2015). Immediately after recording $\mathrm{RR}$, rectal temperature $(\mathbf{R T})$ was measured using a thermometer (Qingdao Dacon Trading Co. Ltd., Shandong, China) placed in the rectum for $1 \mathrm{~min}$.

Behavioral data [eating, ruminating, resting, drinking, standing, lying, and nonnutritive oral behaviors (NNOB)] were monitored visually by trained personnel, unaware of the treatment, during a 12 -h period for 3 consecutive days before weaning (d 58 to 60 of the trial) and after weaning (d 86 to 88 of the trial). A total of 4 individuals in 2-person teams rotated throughout the 12-h period; 2 individuals observed the calves simultaneously for $2 \mathrm{~h}$ with a 2 -h rest period before recording again. All activities were noted every $5 \mathrm{~min}$ and each activity was assumed to persist for the entire 5-min interval between observations (Kargar et al., 2010, 2013, and 2014). A period of eating was defined as at least 1 observation of eating activity occurring after at least 5 min without eating. Meal frequency was defined as the number of bouts during a 12-h period. The meal duration (min/meal) was computed as the time from the beginning of the 1st feeding event until an interval between events, and averaged for each calf. Intervals (min) between feeding events were computed from the end of a feeding event to the beginning of the next, and averaged for each calf. The meal size ( $\mathrm{g}$ of starter DM/meal) was the total amount of starter DM ingested during each meal. The same procedure was used to calculate the rumination pattern. 
Blood samples were collected $4 \mathrm{~h}$ after the morning meal into vacuum tubes on d 63 (weaning day) and 91 of life, placed on ice, and centrifuged at $3,000 \times g$ for 20 min at $4^{\circ} \mathrm{C}$. Serum $(1.5 \mathrm{~mL})$ was transferred into $2-\mathrm{mL}$ cryotubes and stored at $-20^{\circ} \mathrm{C}$. Serum concentration of glucose was determined spectrophotometrically (UNICCO, 2100; Zistchemi, Tehran, Iran) using commercially available kit [Pars Azmoon Co., Tehran, Iran; catalog number: glucose (1-500-017)]. Serum concentrations of insulin, $\mathrm{T}_{3}, \mathrm{~T}_{4}$, and cortisol were determined using ELISA (Bio-Tek Instruments Inc., Winooski, VT) commercial kits (Diaplus Inc., North York, ON, Canada).

\section{Statistical Analyses}

Data were checked for normality using the UNIVARIATE procedure (SAS 9.4, SAS Institute Inc., Cary, NC). The data that were not normally distributed were transformed logarithmically. Starter feed intake, total DMI, ADG, feed efficiency, skeletal growth, RR, and RT values were analyzed for 3 discrete periods as preweaning (d 1 to 63 ), postweaning (d 64 to 91), and overall (d 1 to 91) periods. Data on starter feed intake, total DMI, ADG, feed efficiency, skeletal growth, RR, and RT were analyzed using the MIXED MODEL procedure (SAS 9.4) as

$$
\begin{aligned}
& Y_{i j k l}=\mu+\text { Calf }_{i}+\text { Treatment }_{j}+\text { Time }_{k} \\
& +(\text { Treatment } \times \text { Time })_{j k}+\beta\left(X_{i}-\bar{X}\right)+e_{i j k l},
\end{aligned}
$$

where $Y_{i j k l}$ is the dependent variable; $\mu$ is the average experimental value; Calf $_{i}$ is the random effect of calf; Treatment $t_{i}$ is the fixed effect of $\mathrm{Cr} i(i=0$ and $0.05 \mathrm{mg} /$ $\mathrm{kg}$ of $\left.\mathrm{BW}^{0.75}\right) ;$ Time $_{j}$ is the fixed effect of day or week $j$ $(j=\text { number of day or week); (Treatment } \times \text { Time })_{i j}$ represents the effect of the interaction between treatment and time; $\beta\left(X_{i}-\bar{X}\right)$ designates the covariate variable, where the $\beta$ is the regression coefficient relating covariate factor to the variable measured, $X_{i}$ is the covariate factor for the ith factor, and $\bar{X}$ is the overall mean of covariate factor; and $e_{i j k l}$ is the error term.

Time (day or week) was modeled as a repeated measurement by using an autoregressive covariance structure (type 1), which was determined by the smallest Akaike's information criterion. Initial BW was considered as a covariate for BW (d 63 and 91) and skeletal growth analyses. Least squares means for treatment effects were separated using a Tukey adjustment when the overall $F$-test was $P<0.05$. Trends were declared at $0.05 \leq P \leq 0.10$.
Data on BW, feeding and chewing behavior, and blood variables were subjected to ANOVA according to the following model:

$$
Y_{i j k}=\mu+\text { Calf }_{i}+\text { Treatment }_{j}+e_{i j k}
$$

where $Y_{i j k}$ is the dependent variable; $\mu$ is the average experimental value; Calf $_{i}$ is the random effect of calf; Treatment $t_{j}$ is the fixed effect of $\mathrm{Cr} j(j=0$ and $0.05 \mathrm{mg} /$ $\mathrm{kg}$ of $\left.\mathrm{BW}^{0.75}\right)$; and $e_{i j k}$ is the error term.

\section{RESULTS}

The average maximum THI, $\mathrm{RH}$, and maximum temperature were $81.3,11.5 \%$, and $36.9^{\circ} \mathrm{C}$, respectively, during the experiment (Figure 1).

\section{Feed Intake and Performance}

Results of feed intake, BW, ADG, and FE are shown in Table 2. Calves supplemented with $\mathrm{Cr}$ had greater starter feed intake and total DMI during the preweaning $(P=0.001)$, postweaning $(P=0.04)$, and overall $(P$ $=0.003)$ periods than $\mathrm{Cr}-$ calves. Irrespective of the treatment, total DMI increased with increasing calf age (week effect: $P<0.001$ ). Calves supplemented with $\mathrm{Cr}$ had a higher total DMI at weaning (d 63) as compared with $\mathrm{Cr}-$ calves (treatment $\times$ week effect: $P=0.01$; Figure 2). Initial BW (41.3 vs. $43.0 \mathrm{~kg}$ for $\mathrm{Cr}-$ vs. $\mathrm{Cr}+$ ), and weaning (76.4 vs. $80.8 \mathrm{~kg}$ ) and final (106.8 vs. $114.4 \mathrm{~kg}$ ) weights were not affected by $\mathrm{Cr}$ treatment. Average daily gain was not affected by treatments during the pre- $(0.56$ vs. $0.60 \mathrm{~kg} / \mathrm{d} ; P=0.11)$ or postweaning (1.10 vs. $1.20 \mathrm{~kg} / \mathrm{d} ; P=0.12$ ) periods; however, $\mathrm{Cr}+$ calves had a greater $(P=0.02) \mathrm{ADG}$ during the whole experiment. No differences in feed efficiency were detected between treatments during the preweaning, postweaning, and overall periods $(P>$ 0.05). However, calves supplemented with $\mathrm{Cr}$ tended to have higher ADG (treatment $\times$ week effect: $P=0.07$; Figure 3 ) and a greater feed efficiency (treatment $x$ week effect: $P=0.03$; Figure 4 ) during the first week of study.

\section{Skeletal Growth and Health Status}

Skeletal growth, RR, and RT data are presented in Table 3. Chromium supplementation tended to increase the heart girth during the preweaning $(P=0.05)$ and overall periods $(P=0.10)$, with no difference between treatments during the postweaning period. No differences were observed in body barrel between treatments 
Table 2. Intake, BW, ADG, and feed efficiency of summer-exposed calves supplemented with $(\mathrm{Cr}+)$ or without $(\mathrm{Cr}-)$ chromium

\begin{tabular}{|c|c|c|c|c|c|c|}
\hline \multirow[b]{2}{*}{ Item } & \multicolumn{2}{|c|}{ Treatment } & \multirow[b]{2}{*}{ SEM } & \multicolumn{3}{|c|}{$P$-value ${ }^{1}$} \\
\hline & $\mathrm{Cr}-$ & $\mathrm{Cr}+$ & & $\mathrm{T}$ & W & $\mathrm{T} \times \mathrm{W}$ \\
\hline \multicolumn{7}{|l|}{ Starter intake, $\mathrm{kg}$ of $\mathrm{DM} / \mathrm{d}$} \\
\hline Preweaning (d 1 to 63 ) & $0.39^{\mathrm{b}}$ & $0.50^{\mathrm{a}}$ & 0.03 & 0.001 & $<0.001$ & 0.004 \\
\hline Postweaning (d 64 to 91 ) & $2.07^{\mathrm{b}}$ & $2.31^{\mathrm{a}}$ & 0.08 & 0.04 & $<0.001$ & 0.77 \\
\hline Overall (d 1 to 91$)$ & $0.91^{\mathrm{b}}$ & $1.06^{\mathrm{a}}$ & 0.04 & 0.003 & $<0.001$ & 0.01 \\
\hline \multicolumn{7}{|l|}{ Total DMI, ${ }^{2} \mathrm{~kg} / \mathrm{d}$} \\
\hline Preweaning (d 1 to 63 ) & $1.04^{\mathrm{b}}$ & $1.15^{\mathrm{a}}$ & 0.03 & 0.001 & $<0.001$ & 0.004 \\
\hline Postweaning (d 64 to 91 ) & $2.07^{\mathrm{b}}$ & $2.31^{\mathrm{a}}$ & 0.08 & 0.04 & $<0.001$ & 0.77 \\
\hline Overall (d 1 to 91$)$ & $1.35^{\mathrm{b}}$ & $1.51^{\mathrm{a}}$ & 0.04 & 0.002 & $<0.001$ & 0.01 \\
\hline \multicolumn{7}{|l|}{$\mathrm{BW}, \mathrm{kg}$} \\
\hline Initial (d 1) & 41.25 & 43.00 & 0.89 & 0.17 & - & - \\
\hline At weaning (d 63) & 76.38 & 80.79 & 1.85 & 0.20 & - & - \\
\hline At end (d 91) & 106.83 & 114.39 & 2.45 & 0.14 & - & - \\
\hline \multicolumn{7}{|l|}{$\mathrm{ADG}, \mathrm{kg} / \mathrm{d}$} \\
\hline Preweaning (d 1 to 63 ) & 0.56 & 0.60 & 0.03 & 0.11 & $<0.001$ & 0.06 \\
\hline Postweaning (d 64 to 91 ) & 1.10 & 1.20 & 0.05 & 0.12 & $<0.001$ & 0.20 \\
\hline Overall (d 1 to 91$)$ & $0.72^{\mathrm{b}}$ & $0.79^{\mathrm{a}}$ & 0.02 & 0.02 & $<0.001$ & 0.07 \\
\hline \multicolumn{7}{|l|}{ Feed efficiency ${ }^{3}$} \\
\hline Preweaning (d 1 to 63 ) & 0.50 & 0.51 & 0.02 & 0.80 & $<0.001$ & 0.02 \\
\hline Postweaning (d 64 to 91 ) & 0.54 & 0.52 & 0.02 & 0.47 & $<0.001$ & 0.15 \\
\hline Overall (d 1 to 91$)$ & 0.51 & 0.51 & 0.02 & 0.93 & $<0.001$ & 0.03 \\
\hline
\end{tabular}

${ }^{\mathrm{a}, \mathrm{b}}$ Means within a row with different superscripts are significantly different $(P<0.05)$.

${ }^{1} \mathrm{~T}=$ treatment effect; $\mathrm{W}=$ week effect; and $\mathrm{T} \times \mathrm{W}=$ treatment by week interaction.

${ }^{2}$ Total DMI $=$ milk DM + starter feed DM.

${ }^{3}$ Feed efficiency was calculated by dividing ADG by average total daily DMI (milk DM + starter feed DM).

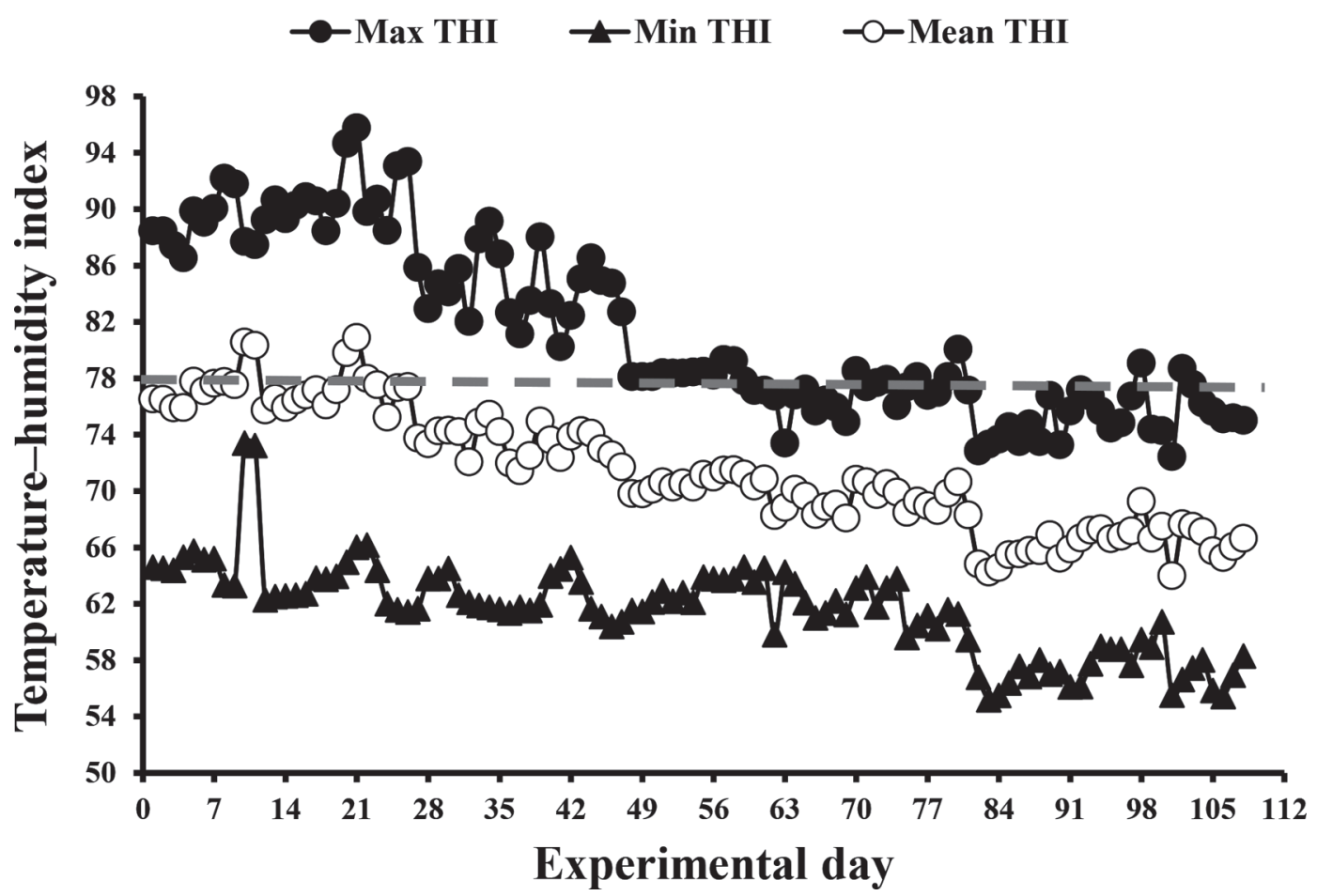

Figure 1. Temporal patterns of minimum (Min), mean, and maximum (Max) temperature-humidity index (THI) over the experimental period. The average maximum THI, relative humidity, and maximum temperature were $81.3,11.5 \%$, and $36.9^{\circ} \mathrm{C}$, respectively. 


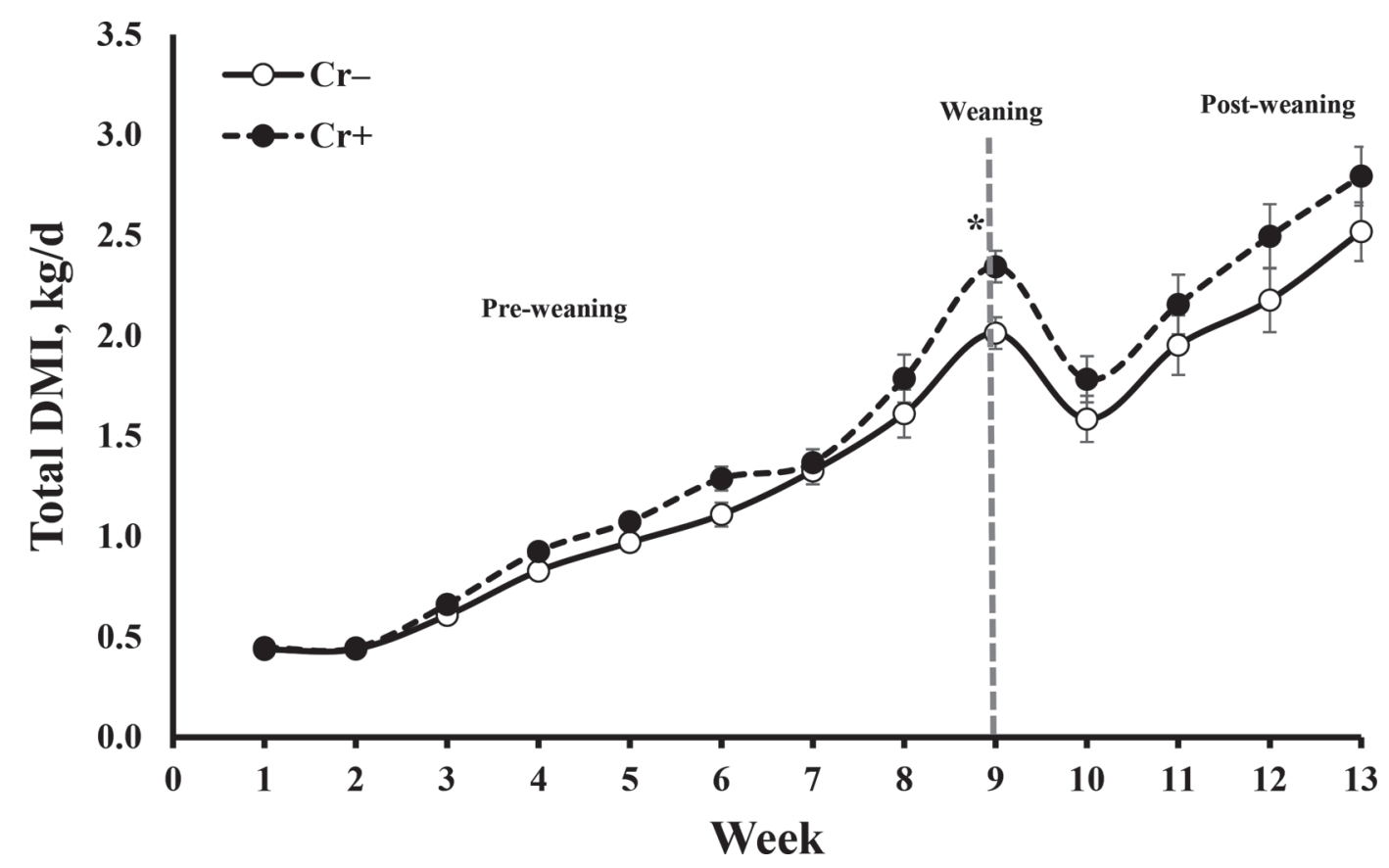

Figure 2. Daily total DMI $( \pm \mathrm{SE} ; \mathrm{kg} / \mathrm{d})$ of calves supplemented with $(\mathrm{Cr}+)$ or without $(\mathrm{Cr}-)$ chromium, over 13 wk of age. SEM $=0.04$. Effects in the model: treatment $(\mathrm{T}): P=0.002$; week $(\mathrm{W}): P<0.001 ; \mathrm{T} \times \mathrm{W}: P=0.01$. For each time point, ${ }^{*}$ denotes significant difference at $P<0.05$.

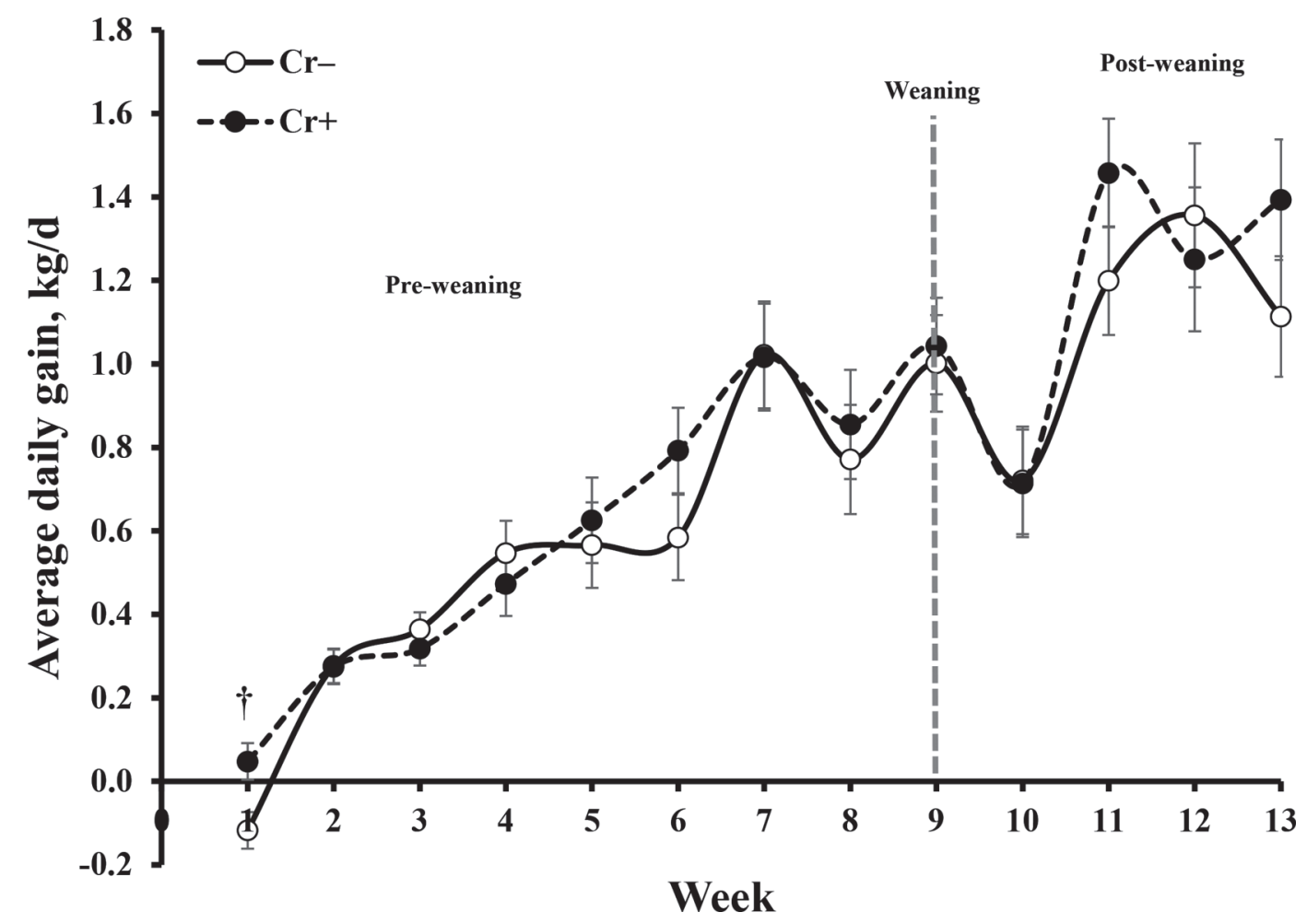

Figure 3. Average daily gain $( \pm \mathrm{SE} ; \mathrm{kg} / \mathrm{d})$ of calves supplemented with $(\mathrm{Cr}+)$ or without $(\mathrm{Cr}-)$ chromium, over 13 wk of age. SEM $=0.02$. Effects in the model: treatment $(\mathrm{T}): P=0.02$; week $(\mathrm{W}): P<0.001 ; \mathrm{T} \times \mathrm{W}: P=0.07$. For each time point, $\dagger$ denotes a tendency to differ at $0.05 \leq P \leq 0.10$. 
Table 3. Skeletal growth, respiration rate, and rectal temperature of summer-exposed calves supplemented with $(\mathrm{Cr}+)$ or without $(\mathrm{Cr}-)$ chromium

\begin{tabular}{|c|c|c|c|c|c|c|}
\hline \multirow[b]{2}{*}{ Item } & \multicolumn{2}{|c|}{ Treatment } & \multirow[b]{2}{*}{ SEM } & \multicolumn{3}{|c|}{$P$-value ${ }^{1}$} \\
\hline & $\mathrm{Cr}-$ & $\mathrm{Cr}+$ & & $\mathrm{T}$ & W & $\mathrm{T} \times \mathrm{W}$ \\
\hline \multicolumn{7}{|l|}{ Heart girth, cm } \\
\hline Preweaning (d 1 to 63 ) & $86.5^{\mathrm{b}}$ & $87.5^{\mathrm{a}}$ & 0.35 & 0.05 & $<0.001$ & 0.56 \\
\hline Postweaning (d 64 to 91$)$ & 103.1 & 103.7 & 0.54 & 0.44 & $<0.001$ & 0.08 \\
\hline Overall (d 1 to 91$)$ & 91.7 & 92.5 & 0.33 & 0.10 & $<0.001$ & 0.27 \\
\hline \multicolumn{7}{|l|}{ Body barrel, $\mathrm{cm}$} \\
\hline Preweaning (d 1 to 63 ) & 93.8 & 94.0 & 0.44 & 0.78 & $<0.001$ & 0.94 \\
\hline Postweaning (d 64 to 91 ) & 119.4 & 120.9 & 0.82 & 0.22 & $<0.001$ & 0.02 \\
\hline Overall (d 1 to 91$)$ & 101.7 & 102.2 & 0.39 & 0.38 & $<0.001$ & 0.32 \\
\hline \multicolumn{7}{|l|}{ Hip width, cm } \\
\hline Preweaning (d 1 to 63 ) & 24.1 & 24.3 & 0.10 & 0.12 & $<0.001$ & 0.29 \\
\hline Postweaning (d 64 to 91 ) & $30.3^{\mathrm{b}}$ & $30.8^{\mathrm{a}}$ & 0.15 & 0.02 & $<0.001$ & 0.53 \\
\hline Overall (d 1 to 91$)$ & $26.0^{\mathrm{b}}$ & $26.3^{\mathrm{a}}$ & 0.08 & 0.01 & $<0.001$ & 0.37 \\
\hline \multicolumn{7}{|l|}{ Respiration rate, breaths/min } \\
\hline Preweaning (d 1 to 63 ) & $41.9^{\mathrm{a}}$ & $39.5^{\mathrm{b}}$ & 0.80 & 0.03 & 0.01 & 0.57 \\
\hline Postweaning (d 64 to 91 ) & 40.2 & 39.2 & 0.73 & 0.35 & 0.13 & 0.45 \\
\hline Overall (d 1 to 91$)$ & $41.4^{\mathrm{a}}$ & $39.4^{\mathrm{b}}$ & 0.60 & 0.02 & 0.01 & 0.51 \\
\hline \multicolumn{7}{|l|}{ Rectal temperature, ${ }^{\circ} \mathrm{C}$} \\
\hline Preweaning (d 1 to 63 ) & 39.08 & 39.07 & 0.02 & 0.86 & 0.04 & 0.35 \\
\hline Postweaning (d 64 to 91 ) & 39.09 & 39.02 & 0.04 & 0.24 & 0.71 & 0.22 \\
\hline Overall (d 1 to 91$)$ & 39.08 & 39.06 & 0.02 & 0.43 & 0.13 & 0.16 \\
\hline
\end{tabular}

$\overline{\mathrm{a}, \mathrm{b}}$ Means within a row with different superscripts are significantly different $(P<0.05)$.

${ }^{1} \mathrm{~T}=$ treatment effect; $\mathrm{W}=$ week effect; and $\mathrm{T} \times \mathrm{W}=$ treatment by week interaction.

$(P>0.05)$. The hip width was greater for $\mathrm{Cr}+$ calves than $\mathrm{Cr}-$ calves during the postweaning and overall periods but not during the preweaning period. Rectal temperature was not affected by treatments $(P>0.05)$, but $\mathrm{RR}$ was significantly lower in $\mathrm{Cr}+$ calves during the preweaning $(P=0.03)$ and overall $(P=0.03)$ periods.

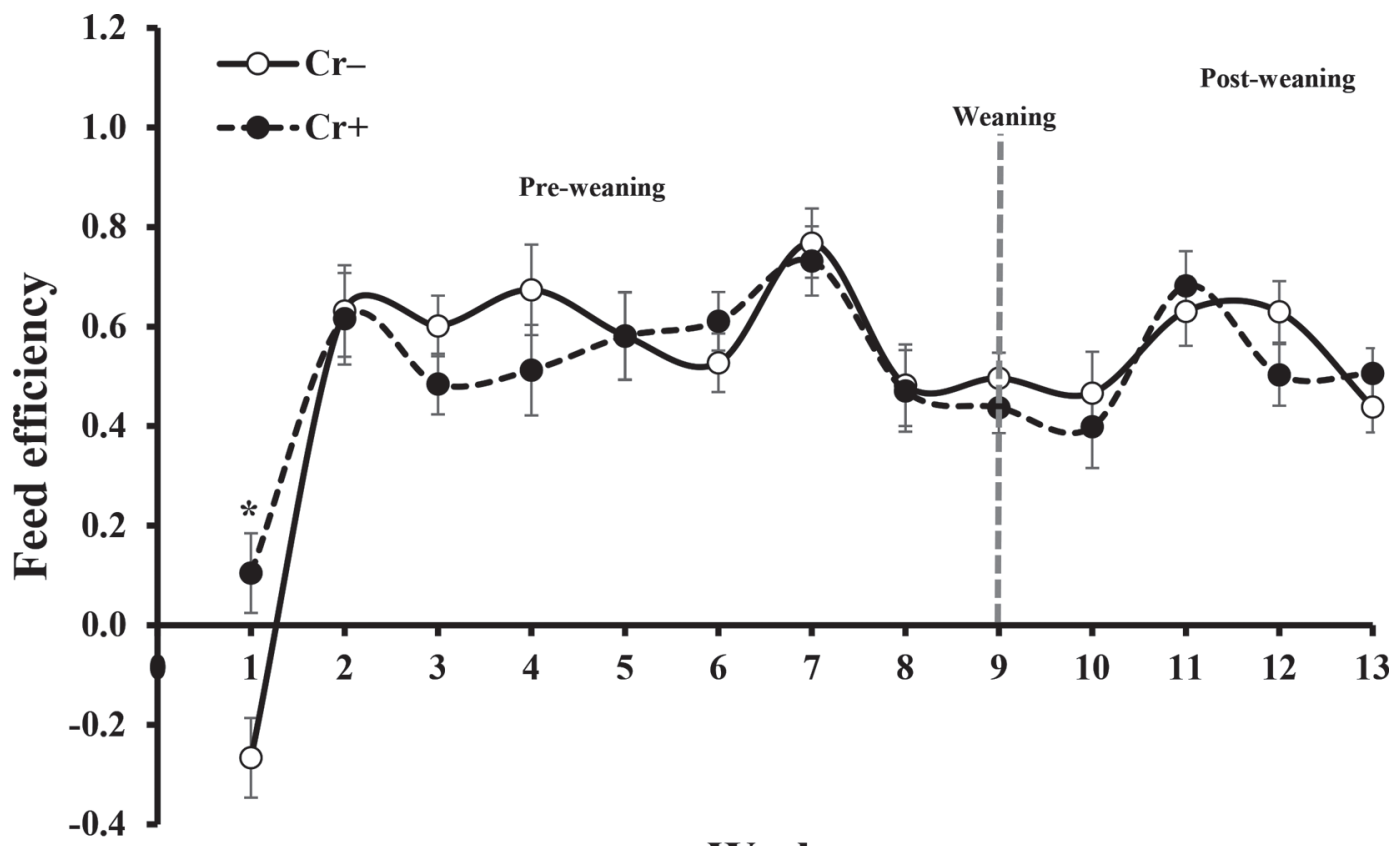

\section{Week}

Figure 4. Feed efficiency $( \pm \mathrm{SE}$; $\mathrm{kg} / \mathrm{d})$ of calves supplemented with $(\mathrm{Cr}+)$ or without $(\mathrm{Cr}-)$ chromium, over 13 wk of age. SEM $=0.02$. Effects in the model: treatment $(\mathrm{T}): P=0.93$; week $(\mathrm{W}): P<0.001 ; \mathrm{T} \times \mathrm{W}: P=0.03$. For each time point, ${ }^{*}$ denotes significant difference at $P<0.05$. 


\section{Chewing Behavior and Meal and Rumination Patterns}

Table 4 presents the total time devoted to each behavior in a 12-h observation period. During the preweaning period, the times spent in eating and ruminating were not affected by treatments $(P>0.05)$. Times devoted to resting, drinking, standing, lying, and in NNOB were not affected by treatments. During the postweaning period, eating time, expressed as minutes per $12 \mathrm{~h}$, increased (128.3 vs. $105.8 \mathrm{~min} ; P=0.03$ ) in $\mathrm{Cr}+$ calves. During the postweaning period, rumination time (min per 12-h period) as well as the times devoted to resting, drinking, standing, lying, and NNOB were not different $(P>0.05)$ between treatments.

The data on meal and rumination patterns are presented in Table 5. During the preweaning period, meal frequency decreased ( 5.2 vs. 6.4 bouts $/ 12 \mathrm{~h} ; P=0.04$ ) but meal duration (14.5 vs. $11.7 \mathrm{~min} / \mathrm{meal} ; P=0.04$ ), meal size (99.8 vs. $72.3 \mathrm{~g}$ of starter DM; $P=0.04$ ), and inter-meal interval (124.0 vs. $100.8 \mathrm{~min} ; P=0.08)$ increased in $\mathrm{Cr}+$ calves. Chromium supplementation decreased the number of rumination bouts $(6.0$ vs. 7.5 per $12 \mathrm{~h} ; P=0.03$ ) during the preweaning period. However, rumination duration ( $\mathrm{min} /$ meal, 19.3 vs. $16.3 ; P$ $=0.06)$ and interval between bouts (100.7 vs. $79.7 \mathrm{~min}$, $P=0.04)$ increased in $\mathrm{Cr}+$ calves compared with $\mathrm{Cr}-$ calves. During the postweaning period, meal patterns were not affected by treatments except for meal length, which tended to be greater for $\mathrm{Cr}+$ calves than for $\mathrm{Cr}-$ calves (15.7 vs. $13.7 \mathrm{~min} ; P=0.08)$. Furthermore, rumination patterns were not different between treatments.

Table 6 presents the overall means of blood glucose and hormone concentrations at weaning and at the end of the trial. At weaning, concentrations of blood glucose, insulin, $\mathrm{T}_{3}, \mathrm{~T}_{4}$, and cortisol, and insulin to glucose and $\mathrm{T}_{3}$ to $\mathrm{T}_{4}$ ratios were not affected by treatments. Blood glucose concentration measured at the end of the trial tended to be lower $(P=0.09)$ in $\mathrm{Cr}+$ calves. Serum concentration of insulin $(P=0.01)$, and insulin to glucose ratio $(P=0.02)$ increased in $\mathrm{Cr}+$ calves compared with $\mathrm{Cr}-$ calves. However, concentrations of cortisol and thyroid hormones, and $T_{3}$ to $T_{4}$ ratio were not affected by $\mathrm{Cr}$ supplementation.

\section{DISCUSSION}

During the experiment, the average maximum THI, $\mathrm{RH}$, and maximum temperature were $81.3,11.5 \%$, and $36.9^{\circ} \mathrm{C}$, respectively, indicating a high environmental heat load (Yari et al., 2010; Beiranvand et al., 2016). We have ignored the potential effect of methionine as a part of Cr-Met supplement in the current study and discussed the results by focusing only on the possible effect of Cr. Chromium concentration in the starter ingredients varies widely and has not always reported due to the difficulty in analysis of $\mathrm{Cr}$. The starter ingredients in the current study contained $0.95 \mathrm{mg} \mathrm{Cr} /$ $\mathrm{kg}$ of DM, which is in the range (approximately 1 to $3 \mathrm{mg}$ of $\mathrm{Cr} / \mathrm{kg}$ of DM) reported by Lindemann (2007). However, the bio-availability of $\mathrm{Cr}$ in the starter feed

Table 4. Chewing behaviors and times devoted to drinking, standing, lying, and nonnutritive oral behaviors of summer-exposed calves supplemented with $(\mathrm{Cr}+)$ or without $(\mathrm{Cr}-)$ chromium

\begin{tabular}{|c|c|c|c|c|}
\hline \multirow[b]{2}{*}{ Item } & \multicolumn{2}{|c|}{ Treatment } & \multirow[b]{2}{*}{ SEM } & \multirow{2}{*}{$\frac{P \text {-value }}{\mathrm{T}}$} \\
\hline & $\mathrm{Cr}-$ & $\mathrm{Cr}+$ & & \\
\hline \multicolumn{5}{|l|}{ Preweaning period (d 58 to 60 ) } \\
\hline Eating time, $\min / 12 \mathrm{~h}$ & 73.3 & 72.9 & 5.78 & 0.95 \\
\hline Ruminating time, $\min / 12 \mathrm{~h}$ & 121.3 & 111.3 & 7.77 & 0.37 \\
\hline Resting time, min & 444.2 & 464.2 & 13.27 & 0.19 \\
\hline Drinking time, min & 12.5 & 14.6 & 1.89 & 0.44 \\
\hline Nonnutritive oral behaviors, ${ }^{2}$ min & 68.8 & 57.1 & 7.55 & 0.28 \\
\hline Standing time, min & 267.9 & 257.1 & 12.83 & 0.55 \\
\hline Lying time, min & 452.1 & 462.9 & 12.83 & 0.55 \\
\hline \multicolumn{5}{|l|}{ Postweaning period (d 86 to 88 ) } \\
\hline Eating time, $\min / 12 \mathrm{~h}$ & $105.8^{\mathrm{b}}$ & $128.3^{\mathrm{a}}$ & 6.92 & 0.03 \\
\hline Ruminating time, $\min / 12 \mathrm{~h}$ & 149.2 & 145.8 & 10.80 & 0.82 \\
\hline Resting time, min & 384.6 & 371.7 & 14.82 & 0.49 \\
\hline Drinking time. min & 20.4 & 23.8 & 3.15 & 0.46 \\
\hline Nonnutritive oral behaviors, ${ }^{2}$ min & 60.0 & 50.4 & 4.40 & 0.13 \\
\hline Standing time, min & 287.5 & 312.1 & 12.46 & 0.17 \\
\hline Lying time, min & 432.5 & 407.9 & 12.46 & 0.17 \\
\hline
\end{tabular}


Table 5. Meal and rumination patterns of summer-exposed calves supplemented with $(\mathrm{Cr}+)$ or without $(\mathrm{Cr}-)$ chromium

\begin{tabular}{|c|c|c|c|c|}
\hline \multirow[b]{2}{*}{ Item } & \multicolumn{2}{|c|}{ Treatment } & \multirow[b]{2}{*}{ SEM } & \multirow{2}{*}{$\frac{P \text {-value }}{1}$} \\
\hline & $\mathrm{Cr}-$ & $\mathrm{Cr}+$ & & \\
\hline \multicolumn{5}{|l|}{ Preweaning period (d 58 to 60 ) } \\
\hline Meal frequency, bouts $/ 12 \mathrm{~h}$ & $6.4^{\mathrm{a}}$ & $5.2^{\mathrm{b}}$ & 0.41 & 0.04 \\
\hline Meal duration, $\mathrm{min} / \mathrm{meal}$ & $11.7^{\mathrm{b}}$ & $14.5^{\mathrm{a}}$ & 0.93 & 0.04 \\
\hline Meal interval, min & 100.8 & 124.0 & 9.30 & 0.08 \\
\hline Meal size, $g$ of starter DM & $72.3^{\mathrm{b}}$ & $99.8^{\mathrm{a}}$ & 9.25 & 0.04 \\
\hline Rumination frequency, bouts $/ 12 \mathrm{~h}$ & $7.5^{\mathrm{a}}$ & $6.0^{\mathrm{b}}$ & 0.46 & 0.03 \\
\hline Rumination bout length, min/bout & 16.3 & 19.3 & 1.09 & 0.06 \\
\hline Rumination bout interval, min & $79.7^{\mathrm{b}}$ & $100.7^{\mathrm{a}}$ & 7.95 & 0.04 \\
\hline \multicolumn{5}{|l|}{ Postweaning period (d 86 to 88 ) } \\
\hline Meal frequency, bouts/12 h & 7.8 & 8.3 & 0.40 & 0.47 \\
\hline Meal duration, $\min /$ meal & 13.7 & 15.7 & 0.77 & 0.08 \\
\hline Meal interval, $\min$ & 78.6 & 71.1 & 5.62 & 0.28 \\
\hline Meal size, $\mathrm{g}$ of starter DM & 171.6 & 170.2 & 13.62 & 0.94 \\
\hline Rumination frequency, bouts $/ 12 \mathrm{~h}$ & 7.5 & 6.4 & 0.44 & 0.19 \\
\hline Rumination bout length, min/bout & 20.9 & 22.6 & 1.14 & 0.31 \\
\hline Rumination bout interval, min & 75.1 & 89.9 & 7.75 & 0.21 \\
\hline
\end{tabular}

${ }_{\mathrm{a}, \mathrm{b}}$ Means within a row with different superscripts are significantly different $(P<0.05)$.

${ }^{1} \mathrm{~T}=$ treatment effect.

ingredients is lower than that in Cr-Met (Lindemann, 2007). Accordingly, we attempted to supplement an additional $2 \mathrm{mg}$ of $\mathrm{Cr} / \mathrm{d}$ to determine its effect on growth performance, feeding behavior, and well-being of dairy calves.

In the current study, Cr supplementation increased starter feed intake and total DMI in summer-exposed calves, which indicates that $\mathrm{Cr}$ may have been deficient in calves. It has been reported that $\mathrm{Cr}$ requirement of calves is increased under a variety of stress conditions (Chang and Mowat, 1992; Pechova and Pavlata,
2007). A major break in the heat load occurred at 49 $\mathrm{d}$, resulting in a drop of 8 to 10 units in the maximum THI (Figure 1), which may have exacerbated the feed intake difference between the 2 treatments (Figure 2), and perhaps generated the treatment by week interaction on the feed intake (Table 2). Regardless of the environmental heat load, the birth and weaning processes can be stressful for the calf (Jonasen and Krohn, 1991; Murray and Leslie, 2013). Stressful situations may increase the urinary excretion and thus Cr requirements (Chang and Mowat, 1992; Pechova and Pavlata,

Table 6. Blood serum metabolite and hormones of summer-exposed calves supplemented with $(\mathrm{Cr}+)$ or without $(\mathrm{Cr}-)$ chromium

\begin{tabular}{|c|c|c|c|c|}
\hline \multirow[b]{2}{*}{ Item } & \multicolumn{2}{|c|}{ Treatment } & \multirow[b]{2}{*}{ SEM } & \multirow{2}{*}{$\frac{P \text {-value }}{\mathrm{T}}$} \\
\hline & $\mathrm{Cr}-$ & $\mathrm{Cr}+$ & & \\
\hline \multicolumn{5}{|l|}{ At weaning (d 63) } \\
\hline Glucose, $\mathrm{mg} / \mathrm{dL}$ & 97.40 & 93.80 & 2.00 & 0.23 \\
\hline Insulin, $\mu \mathrm{IU} / \mathrm{mL}$ & 13.82 & 20.20 & 5.90 & 0.46 \\
\hline Insulin:glucose & 0.14 & 0.21 & 0.06 & 0.44 \\
\hline Triiodothyronine $\left(\mathrm{T}_{3}\right), \mathrm{ng} / \mathrm{dL}$ & 176 & 148 & 13.6 & 0.18 \\
\hline Thyroxine $\left(\mathrm{T}_{4}\right), \mu \mathrm{g} / \mathrm{dL}$ & 6.42 & 5.22 & 0.55 & 0.16 \\
\hline $\mathrm{T}_{3}: \mathrm{T}_{4}$ & 28.34 & 29.08 & 3.33 & 0.87 \\
\hline Cortisol, $\mu \mathrm{g} / \mathrm{dL}$ & 1.78 & 1.12 & 0.31 & 0.18 \\
\hline \multicolumn{5}{|l|}{ At end (d 91) } \\
\hline Glucose, mg/dL & 97.20 & 93.00 & 2.43 & 0.09 \\
\hline Insulin, $\mu \mathrm{IU} / \mathrm{mL}$ & $10.04^{\mathrm{b}}$ & $31.94^{\mathrm{a}}$ & 4.87 & 0.01 \\
\hline Insulin:glucose & $0.11^{\mathrm{b}}$ & $0.34^{\mathrm{a}}$ & 0.05 & 0.02 \\
\hline $\mathrm{T}_{3}, \mathrm{ng} / \mathrm{dL}$ & 202 & 268 & 28.0 & 0.13 \\
\hline $\mathrm{T}_{4}, \mu \mathrm{g} / \mathrm{dL}$ & 7.84 & 8.38 & 0.98 & 0.70 \\
\hline $\mathrm{T}_{3}: \mathrm{T}_{4}$ & 26.86 & 31.90 & 2.63 & 0.21 \\
\hline Cortisol, $\mu \mathrm{g} / \mathrm{dL}$ & 1.16 & 1.38 & 0.98 & 0.54 \\
\hline
\end{tabular}

${ }^{\mathrm{a}, \mathrm{b}}$ Means within a row with different superscripts are significantly different $(P<0.05)$.

${ }^{1} \mathrm{~T}=$ treatment effect. 
2007; Yari et al., 2010). In studies performed under normal conditions, Cr supplementation did not affect the starter feed intake or total DMI (Bunting et al., 2000; Ghorbani et al., 2012). It seems that calves in the present study may have experienced some type of stress at birth or weaning. According to Yari et al. (2010), Cr supplementation (either 0.02 or $0.04 \mathrm{mg} / \mathrm{kg}$ of $\mathrm{BW}^{0.75}$ ) to the starter diets had no effects on preweaning total DMI, but decreased total DMI in postweaning calves in summer. Part of the reason for this discrepancy may be explained by differences in the level of supplementation and method of offering $\mathrm{Cr}$ (milk only or colostrum plus milk).

Unlike previous research (Yari et al., 2010; Kumar et al., 2015) in which supplemented and nonsupplemented calves had similar weight gain, $\mathrm{Cr}+$ calves in the current study had greater overall ADG, structural growth (hip width and heart girth), and numerically greater BW measured at weaning $(+4.4 \mathrm{~kg})$ and at the end of the trial $(+7.6 \mathrm{~kg})$ than $\mathrm{Cr}-$ calves. However, $\mathrm{Cr}$ acted fast to improve ADG during the first week but its effect disappeared after $2 \mathrm{wk}$ of supplementation. One possible cause of this improved ADG could be the greater starter feed intake relative to $\mathrm{Cr}-$ calves (Ghorbani et al., 2012). Similarly, Ghorbani et al. (2012) reported a positive effect of adding $\mathrm{Cr}$ to colostrum and milk on weight gain in dairy calves under normal conditions. Part of the discrepancy between our results and others might be due to the source of Cr (Kegley and Spears, 1995).

The RT was normal and similar between treatments, indicating a reasonable calf capability to overcome the potential stresses in the present trial. The respiratory rates of 39 to 42 breaths per minute in summer-exposed calves were similar to those observed in dairy calves during the summer (40-43 per minute; Yari et al., 2010), but was greater than the respiratory rates under normal conditions (31-34 per minute; Ghorbani et al., 2012). Our results are similar to those of Yari et al. (2010), who showed that RR at wk 5 was decreased in Cr-supplemented individuals. The decrease in RR in $\mathrm{Cr}+$ calves may indicate that they suffered less heat load accompanied by greater well-being. The conserved energy may have been directed at increasing the final BW (which was numerically greater in $\mathrm{Cr}+$ calves than in $\mathrm{Cr}$ - calves) or used to mitigate the higher metabolic heat production due to the increased DMI.

To our knowledge, the effect of $\mathrm{Cr}$ supplementation on meal patterns in calves has not been reported previously. Analysis of meal patterns in young calves may be helpful in clarifying the questions about the short-term control of feed intake (Allen et al., 2009; Kargar et al., 2010, 2013). In the current study, meal and rumination patterns were greatly influenced by $\mathrm{Cr}$ supplementation. The meal frequency (5-6 meals in 12 h) was similar to that observed in dairy calves eating solid feed (Miller-Cushon et al., 2015), but was lower than that in dairy cows (Kargar et al., 2010, 2013, 2014). Meal size (27.6\%) and meal duration (19.3\%) increased, but the meal frequency $(23.1 \%)$ decreased in $\mathrm{Cr}+$ calves compared with $\mathrm{Cr}-$ calves. Despite lowered meal frequency, $\mathrm{Cr}+$ calves had similar time to eating intervals $(\mathrm{min} / 12 \mathrm{~h})$.

Feed intake is a function of meal size and meal frequency, determined by satiety and hunger, respectively (Allen et al., 2009). In fact, the temporal patterns of fuel absorption, mobilization, and metabolism can affect the feed intake in ruminants by altering the meal size and frequency (Allen et al., 2009). Of fuels metabolized by the ruminant liver, propionate is probably a primary satiety signal because its flux into the liver increases greatly during meals. Propionate is used for gluconeogenesis or oxidized in the liver and stimulates oxidation of acetyl CoA. Accordingly, meals can be terminated by signals carried from the liver to the brain via afferents in the vagus nerve, and hepatic oxidation of fuels (including propionate) and generation of ATP (Allen et al., 2009) affect these signals. In the current study, an increase in starter feed intake (by larger meal size and longer meal length) and a decrease in RR may indicate that $\mathrm{Cr}+$ calves can cope better with environmental heat load and cause a reduction in meal frequency as calves become metabolically capable of consuming more starter feed per meal. We supposed that this increase in starter feed intake may have increased rumen propionate formation (although we did not measure it) and flux into the liver and thereby terminated the meals and reduced meal frequency. However, further studies are warranted to confirm this supposition.

The environmental heat load may have also decreased the rumination activity (Soriani et al., 2013). In heat-loaded animals, the fractional digesta passage rate in the gastrointestinal tract is slower, reflecting reduced rumen motility and thereby decreasing the feed intake (Silanikove, 1992). The lack of treatment effect on rumination time may be an indication of no severe environmental heat load imposed on the calves in the present study. The mechanism(s) by which $\mathrm{Cr}$ affected the rumination patterns remains unclear, but might involve the insulin-potentiating pathway. Evidence indicates that insulin has a stimulatory effect on rumination by increasing glucose entry in the cells and thereby reticulo-rumen motility (Bareille and Faverdin, 1996). Bareille and Faverdin (1996) reported increased rumination time when glucose was infused intravenously $(2.75 \mathrm{mmol} / \mathrm{kg})$ to dairy cows. However, supplemental $\mathrm{Cr}$ did not affect blood insulin concentration at weaning, and rumination time during the 
preweaning period in the current study, despite the fact that rumination patterns changed (decreased rumination frequency and increased rumination duration and interval). Therefore, the relationship between blood insulin concentration and rumination patterns needs to be investigated further.

Chromium supplementation had small effects on blood glucose and insulin in calves under normal or heat-stress conditions (Yari et al., 2010; Ghorbani et al., 2012). Kumar et al. (2015) reported reduced blood insulin concentration in heat-stressed buffalo calves when $\mathrm{Cr}$ was supplemented at 1 and $1.5 \mathrm{mg} / \mathrm{kg}$ of DMI but not at $0.5 \mathrm{mg} / \mathrm{kg}$ of DMI. Consistent with our results, Bunting et al. (2000) reported that blood concentrations of glucose and insulin decreased and increased, respectively, when dairy calves were supplemented with $0.5 \mathrm{mg}$ of $\mathrm{Cr} / \mathrm{kg}$ of DMI. Chromium supplementation increased insulin concentration and insulin to glucose ratio (an indirect indicator of insulin sensitivity), suggesting that more insulin was needed to remove glucose from the blood (less tissue sensitivity to insulin) and that resistance to insulin increased over that time period (Bunting et al., 2000).

Calves in the present study did not show any change in blood concentrations of $T_{3}$ and $T_{4}$. Similar findings were observed in buffalo calves that received $0.5,1$, and $1.5 \mathrm{mg}$ of $\mathrm{Cr} / \mathrm{kg}$ of DMI (Kumar et al., 2015). However, $\mathrm{Cr}$ supplementation $(0.03 \mathrm{mg}$ of $\mathrm{Cr} / \mathrm{kg}$ of $\mathrm{BW}^{0.75}$ ) increased blood $\mathrm{T}_{4}$ concentration and reduced $\mathrm{T}_{3}$ to $\mathrm{T}_{4}$ ratio in dairy calves (Ghorbani et al., 2012). In contrast, increasing $\mathrm{Cr}$ doses (from 0 to 0.02 and 0.04 $\mathrm{mg} \mathrm{Cr} / \mathrm{kg}$ of $\mathrm{BW}^{0.75}$ ) resulted in quadratic reduction in serum $\mathrm{T}_{4}$, whereas blood $\mathrm{T}_{3}$ decreased only with the higher $\mathrm{Cr}$ dose supplementation in dairy calves (Yari et al., 2010).

Our data did not support a reduction in serum cortisol concentrations in response to $\mathrm{Cr}$ supplementation. Some previous studies reported that Cr supplementation decreased sensitivity to stress by diminishing blood cortisol concentrations in birth-stressed dairy calves (Ghorbani et al., 2012), in feeder calves under transportation stress (Moonsie-Shageer and Mowat, 1993), and in goats under a short-term $(72 \mathrm{~h})$ feed restriction (Haldar et al., 2006). Nevertheless, supplemental Cr did not change (Arthington et al., 1997) or increased (Yari et al., 2010) serum concentration of cortisol in calves inoculated with bovine herpesvirus-1 or experiencing heat stress conditions, respectively. Such inconsistencies may be explained by such factors as species, age, the level, type, and duration of stress, and also type and duration of $\mathrm{Cr}$ supplementation. However, the relationship between $\mathrm{Cr}$ and blood cortisol concentration needs to be clarified further.

\section{CONCLUSIONS}

Chromium supplementation to environmentally heatloaded dairy calves increased the feed intake via larger meal size and longer meal duration despite reducing the meal frequency. Chromium-supplemented calves performed similarly in terms of BW and feed efficiency compared with $\mathrm{Cr}-$ calves. Blood glucose concentration was not different between treatment groups, but blood insulin concentration and insulin to glucose ratio were higher in $\mathrm{Cr}+$ calves at d 91 of age. In general, Cr supplementation may be beneficial in heat stress abatement by reducing $\mathrm{RR}$ and increasing feed intake in dairy calves; but its effect on growth performance may be marginal.

\section{ACKNOWLEDGMENTS}

The authors thank Shahrekord University (Shahrekord, Iran) for partially funding this research and especially for providing suitable experimental conditions. The authors express their appreciation to the farm staff at FKA Agri-Animal Production Company (Isfahan, Iran), for diligent animal care and to Sana Dam Company (Tehran, Iran) for donating Cr-Met. The authors also express their appreciation to Keith Inskeep (emeritus professor, West Virginia University) and Mohammad Javad Zamiri (emeritus professor, Shiraz University) for editing the final English version of this manuscript.

\section{REFERENCES}

Allen, M. S., B. J. Bradford, and M. Oba. 2009. Board-invited review: The hepatic oxidation theory of the control of feed intake and its application to ruminants. J. Anim. Sci. 87:3317-3334.

AOAC International. 1990. Official Methods of Analysis, 15th ed. Association of Official Analytical Chemists, Arlington, VA.

Arthington, J. D., L. R. Corah, J. E. Minton, T. H. Elsasser, and F. Blecha. 1997. Supplemental dietary chromium does not influence $\mathrm{ACTH}$, cortisol, or immune responses in young calves inoculated with bovine herpesvirus-1. J. Anim. Sci. 75:217-223.

Bareille, N., and P. Faverdin. 1996. Modulation of the feeding response of lactating dairy cows to peripheral insulin administration with or without a glucose supply. Reprod. Nutr. Dev. 36:83-93.

Beiranvand, H., M. Khani, S. Omidian, M. Ariana, R. Rezvani, and M. H. Ghaffari. 2016. Does adding water to dry calf starter improve performance during summer? J. Dairy Sci. 99:1903-1911.

Bunting, L. D., T. A. Tarifa, B. T. Crochet, J. M. Fernandez, C. L. Depew, and J. C. Lovejoy. 2000. Effects of dietary inclusion of chromium propionate and calcium propionate on glucose disposal and gastrointestinal development in dairy calves. J. Dairy Sci. 83:2491-2498.

Chang, X., and D. N. Mowat. 1992. Supplemental chromium for stressed and growing feeder calves. J. Anim. Sci. 70:559-565.

Ghorbani, A., H. Sadri, A. R. Alizadeh, and R. M. Bruckmaier. 2012. Performance and metabolic responses of Holstein calves to supplemental chromium in colostrum and milk. J. Dairy Sci. 95:57605769 . 
Haldar, S., T. K. Ghosh, M. C. Pakhira, and K. De. 2006. Effects of incremental dietary chromium $\left(\mathrm{Cr}^{3+}\right)$ on growth, hormone concentrations and glucose clearance in growing goats (Capra hircus). J. Agric. Sci. 144:269-280.

Iranian Council of Animal Care. 1995. Guide to the Care and Use of Experimental Animals, Vol. 1. Isfahan University of Technology, Isfahan, Iran.

Jonasen, B., and C. C. Krohn. 1991. Cow-calf relations 4. Behaviour, production and health in suckler calves. Report 689 from the National Institute of Animal Science, Denmark.

Kargar, S., G. R. Ghorbani, V. Fievez, and D. J. Schingoethe. 2015. Performance, bioenergetic status, and indicators of oxidative stress of environmentally heat-loaded Holstein cows in response to diets inducing milk fat depression. J. Dairy Sci. 98:4772-4784.

Kargar, S., G. R. Ghorbani, M. Khorvash, E. Kamalian, and D. J. Schingoethe. 2013. Dietary grain source and oil supplement: Feeding behavior and lactational performance of Holstein cows. Livest. Sci. 157:162-172.

Kargar, S., G. R. Ghorbani, M. Khorvash, A. Sadeghi-Sefidmazgi, and D. J. Schingoethe. 2014. Reciprocal combinations of barley and corn grains in oil-supplemented diets: Feeding behavior and milk yield of lactating cows. J. Dairy Sci. 97:7001-7011.

Kargar, S., M. Khorvash, G. R. Ghorbani, M. Alikhani, and W. Z. Yang. 2010. Short communication: Effects of dietary fat supplements and forage:concentrate ratio on feed intake, feeding, and chewing behavior of Holstein dairy cows. J. Dairy Sci. 93:42974301.

Kegley, E. B., and J. W. Spears. 1995. Immune response, glucose metabolism, and performance of stressed feeder calves fed inorganic or organic chromium. J. Anim. Sci. 73:2721-2726.

Kumar, M., H. Kaur, R. S. Deka, V. Mani, A. K. Tyagi, and G. Chandra. 2015. Dietary inorganic chromium in summer-exposed buffalo calves (Bubalus bubalis): Effects on biomarkers of heat stress, immune status, and endocrine variables. Biol. Trace Elem. Res. $167: 18-27$.

Lindemann, M. D. 2007. Use of chromium as an animal feed supplement. Pages 85-118 in The Nutritional Biochemistry of Chromium (III). J. B. Vincent, ed. Elsevier, Amsterdam, the Netherlands.

Miller-Cushon, E. K., J. P. Vogel, and T. J. DeVries. 2015. Short communication: Feed sorting of dairy heifers is influenced by method of dietary transition. J. Dairy Sci. 98:2687-2692.

Moonsie-Shageer, S., and D. N. Mowat. 1993. Effect of level of supplemental chromium on performance, serum constituents and immune status of stress feeder calves. J. Anim. Sci. 71:232-238.

Murray, C. F., and K. E. Leslie. 2013. Newborn calf vitality: Risk factors, characteristics, assessment, resulting outcomes and strategies for improvement. Vet. J. 198:322-328.

Nasrollahi, S. M., M. Khorvash, G. R. Ghorbani, A. Teimouri-Yansari, A. Zali, and Q. Zebeli. 2012. Grain source and marginal changes in forage particle size modulate digestive processes and nutrient intake of dairy cows. Animal 6:1237-1245.

NRC. 2001. Nutrient Requirement of Dairy Cattle. 7th rev. ed. Natl. Acad. Sci., Washington, DC.

Pazoki, A., G. R. Ghorbani, S. Kargar, A. Sadeghi-Sefidmazgi, J. K. Drackley, and M. H. Ghaffari. 2017. Growth performance, nutrient digestibility, ruminal fermentation, and rumen development of calves during transition from liquid to solid feed: Effects of physical form of starter feed and forage provision. Anim. Feed Sci. Technol. 234:173-185.

Pechova, A., and L. Pavlata. 2007. Chromium as an essential nutrient: A review. Vet. Med. 52:1-18.

Roland, L., M. Drillich, D. Klein-Jöbstl, and M. Iwersen. 2016. Invited review: Influence of climatic conditions on the development, performance, and health of calves. J. Dairy Sci. 99:2438-2452.

Sadri, H., G. R. Ghorbani, H. R. Rahmani, A. H. Samie, M. Khorvash, and R. M. Bruckmaier. 2009. Chromium supplementation and substitution of barley grain with corn: Effects on performance and lactation in periparturient dairy cows. J. Dairy Sci. 92:5411-5418.

Silanikove, N. 1992. Effects of water scarcity and hot environment on appetite and digestion in ruminants: A review. Livest. Prod. Sci. 30:175-194.

Soltan, M. A. 2010. Effect of dietary chromium supplementation on productive and reproductive performance of early lactating dairy cows under heat stress. J. Anim. Physiol. Anim. Nutr. (Berl.) 94:264-272.

Soriani, N., G. Panella, and L. Calamari. 2013. Rumination time during the summer season and its relationships with metabolic conditions and milk production. J. Dairy Sci. 96:5082-5094.

Spain, J. N., and D. E. Spiers. 1996. Effects of supplemental shade on thermoregulatory response of calves to heat challenge in a hutch environment. J. Dairy Sci. 79:639-646.

Tao, S., and G. E. Dahl. 2013. Invited review: Heat stress effects during late gestation on dry cows and their calves. J. Dairy Sci. 96:4079-4093.

Van Soest, P. J., J. B. Robertson, and B. A. Lewis. 1991. Methods for dietary fiber, neutral detergent fiber nonstarch polysaccharide in relation to animal nutrition. J. Dairy Sci. 74:3583-3597.

Vincent, J. B. 2014. Review: Is chromium pharmacologically relevant? J. Trace Elem. Med. Biol. 28:397-405.

Vincent, J. B. 2015. Is the pharmacological mode of action of chromium (III) as a second messenger? Biol. Trace Elem. Res. 166:7-12.

West, J. W. 2003. Effects of heat-stress on production in dairy cattle. J. Dairy Sci. 86:2131-2144.

Yari, M., A. Nikkhah, M. Alikhani, M. Khorvash, H. Rahmani, and G. R. Ghorbani. 2010. Physiological calf responses to increased chromium supply in summer. J. Dairy Sci. 93:4111-4120. 